\title{
Relevansi Pendidikan Musik Terhadap Kecerdasan Intelektual Anak Usia Dini
}

\author{
Winda Oktaviani \\ Universitas Khairun Ternate \\ Jl. Bandara Baabullah Kampus 1 Unkhair, Kelurahan Akehuda Kota Ternate Kode Pos 97728 \\ Email: windaoktaviani@gmail.com
}

\begin{abstract}
Abstrak: Penelitian ini bertujuan untuk mengetahui relevansi pendidikan musik terhadap kecerdasan intelektual pada anak usia dini. Metode yang digunakan dalam penelitian ini adalah metode kualitatif. Sedangkan pendekatan dalam penelitian ini menggunakan pendekatan library research. Hasil penelitian membuktikan bahwa erat kaitannya antara kemahiran bermain musik dengan kecerdasan intelektual. Anak-anak yang mendapatkan program pendidikan musik, meningkat inteligensi spasialnya (kecerdasan ruang) dibandingkan dengan anak-anak yang tidak diekspos oleh musik. Bukan hanya sekedar kecerdasan spasial, musik juga meningkatkan kemampuan bahasa dan kosa kata anak serta logika yang pada akhirnya si anak mampu mengorganisasi ide dan mampu memecahkan masalah.
\end{abstract}

Kata Kunci : Musik, Kecerdasan Intelektual, Anak

\begin{abstract}
This study aims to determine the relevance of music education to intellectual intelligence in early childhood. The method used in this research is qualitative method. While the approach in this study uses a library research approach. The results of the study prove that there is a close relationship between music playing skills and intellectual intelligence. Children who received a music education program increased their spatial intelligence (spatial intelligence) compared to children who were not exposed to music. Not only spatial intelligence, music also improves children's language and vocabulary skills as well as logic which in the end the child is able to organize ideas and be able to solve problems.
\end{abstract}

Keyword : Music, Intellectual Intelligence, Children

\section{A. Pendahuluan}

Pendidikan Anak Usia Dini adalah suatu upaya pembinaan yang dilakukan melalui pemberian rangsangan pendidikan untuk membantu pertumbuhan dan perkembangan jasmani dan rohani. Namun, tidak banyak orang tua yang mampu membina pertumbuhan dan perkembangan anaknya. Mereka kadang kurang memperhatikan dengan baik bakat dan minat yang dimiliki sang anak. Padahal menurut ahli psikologi perkembangan anak usia dini pada usia 0-6 tahun merupakan masa golden age yaitu masa keemasan dalam perkembangan manusia seutuhnya. Masa emas yang dimaksud adalah adanya fakta penelitian bahwa masa ini tidak kurang dari 100 miliar sel otak siap untuk dirangsang agar kecerdasan seseorang dapat berkembang dengan optimal.

Seni merupakan suatu ungkapan yang dihasilkan oleh si penciptanya apakah itu berupa suatu karya benda maupun tak benda. Seni untuk anak-anak berbeda dengan seni untuk orang dewasa karena karakter fisik maupun mentalnya berbeda. Hal ini penting diperhatikan khususnya dalam melakukan penilaian karya anak didik, supaya hasil kreasi anak tidak diukur menurut selera dan kriteria keindahan orang dewasa. Fungsi seni dalam 
pendidikan berbeda dengan fungsi seni dalam kerja profesional. Seni untuk pendidikan difungsikan sebagai media untuk memenuhi fungsi perkembangan anak, baik fisik maupun mental. Sedang seni dalam kerja profesional difungsikan untuk meningkatkan kemampuan bidang keahliannya secara professional.

Dalam pelaksanaan pembelajaran seni di sekolah, pengalaman belajar mencipta seni disebut sebagai pembelajaran berkarya. Sedang pengalaman persepsi, melihat, dan menghayati serta memahami seni disebut pembelajaran apresiasi. Pembelajaran berkarya seni mengandung dua aspek kompetensi, yaitu: keterampilan dan kreativitas.

\section{B. Kerangka Teoretik}

\section{Pengertian Seni}

Sejak Kata "seni" adalah sebuah kata yang semua orang di pastikan mengenalnya, walaupun dengan kadar pemahaman yang berbeda. Konon kata seni berasal dari kata "sani" yang artinya "Jiwa Yang Luhur/ Ketulusan jiwa". Dalam bahasa Inggris dengan istilah "ART" (artivisial) yang artinya adalah barang/atau karya dari sebuah kegiatan. Konsep seni terus berkembang sejalan dengan berkembangnya kebudayaan dan kehidupan masyarakat yang dinamis. Berikut beberapa pendapat tentang pengertian seni:

\section{a. Ensiklopedia Indonesia:}

Seni adalah penciptaan benda atau segala hal yang karena kendahan bentuknya, orang senang melihat dan mendengar

b. Aristoteles:

seni adalah kemampuan membuat sesuatu dalam hubungannya dengan upaya mencapai suatu tujuan yang telah ditentukan oleh gagasan tertentu,

c. Ki Hajar Dewantara:

seni adalah indah, menurutnya seni adalah segala perbuatan manusia yang timbul dan hidup perasaannya dan bersifat indah hingga dapat menggerakkan jiwa perasaan manusia lainnya,

d. Akhdiat K. Mihardja:

seni adalah kegiatan manusia yang merefleksikan kenyataan dalam sesuatu karya, yang berkat bentuk dan isinya mempunyai daya untuk membangkitkan pengalaman tertentu dalam alam rohani sipenerimanya.

e. Erich Kahler:

seni adalah suatu kegiatan manusia yang menjelajahi, menciptakan realitas itu dengan symbol atau kiasan tentang keutuhan "dunia kecil" yang mencerminkan "dunia besar".

\section{Pengertian Musik}

Musik adalah salah satu media ungkapan kesenian, musik mencerminkan kebudayaan masyarakat pendukungnya dengan unsur utamanya adalah suara. Di dalam musik terkandung nilai dan norma-norma yang menjadi bagian dari proses enkulturasi budaya, baik dalam bentuk formal maupun informal. 
Dalam Kamus Besar Bahasa Indonesia (1990: 602) musik adalah: ilmu atau seni menyusun nada atau suara diutarakan, kombinasi dan hubungan temporal untuk menghasilkan komposisi (suara) yang mempunyai keseimbangan dan kesatuan, nada atau suara yang disusun sedemikian rupa sehingga mengandung irama, lagu dan keharmonisan (terutama yang dapat menghasilkan bunyi-bunyi).

Sehingga Seni musik adalah cetusan ekspresi perasaan atau pikiran yang dikeluarkan secara teratur dalam bentuk bunyi. Bisa dikatakan, bunyi (suara) adalah elemen musik paling dasar. Suara musik yang baik adalah hasil interaksi dari tiga elemen, yaitu: irama, melodi, dan harmoni. Irama adalah pengaturan suara dalam suatu waktu, panjang, pendek dan temponya, dan ini memberikan karakter tersendiri pada setiap musik. Kombinasi beberapa tinggi nada dan irama akan menghasilkan melodi tertentu. Selanjutnya, kombinasi yang baik antara irama dan melodi melahirkan bunyi yang harmoni.

\section{Seni Dalam Pengembangan Potensi Anak}

Anak adalah pribadi yang unik memiliki kemampuan dan kebutuhan yang berbeda dengan orang dewasa, dan salah satu kebutuhan anak yang khas adalah kebutuhan mengekspresikan diri atau menyatakan diri. Pendidikan seni dapat memberikan kontribusi kepada perkembangan pribadi anak (siswa). Kontribusi yang dimaksud berkaitan dengan pemberian ruang berekspresi, pengembangan potensi kreatif dan imajinatif, peningkatan kepekaan rasa, menumbuhkan rasa percaya diri, dan pengembangan wawasan budaya.

Pertama, ruang bagi ekspresi diri, artinya seni menjadi wahana untuk mengungkapkan keinginan, perasaan, pikiran melalui berbagai bentuk aktivitas seni sehingga menimbulkan kesenangan dan kepuasaan. Sejumlah penelitian telah meyakinkan bahwa 90 persen komunikasi emosi disampaikan tanpa kata-kata, keterampilan ini dapat sangat meningkatkan kemampuan anak memahami perasaan orang lain sehingga mampu bertindak cepat (Shapiro dalam M. Jazuli, 2008). Ekspresi diri juga bermakna aktualisasi diri karena apa yang diungkapkan melibatkan sosok subjek yang menampilkan/ mengungkapkan kepada orang lain. Berekspresi juga dapat dimaknai bermain karena bermain adalah pekerjaan anak yang bisa memberikan kebebasan, kesenangan, dan tantangan sebagaimana ketika mereka bermain. Melalui permainan anak $\neg$ anak akan memperoleh kesempatan belajar dan mempraktikkan cara-cara baru dalam berpikir, merasakan, dan bertindak. Dengan demikian berekspresi berarti pembelajaran emosi yang selalu melibatkan daya kreasi sering muncul secara spontan ketika Si anak mengungkapkan sesuatu, berkomunikasi, dan bermain.

Kedua, pengembangan potensi kreatif. Potensi kreatif ditandai oleh kemampuan berpikir kritis, rasa ingin tahu menonjol, percaya diri, sering melontarkan gagasan baru orisinil, berani mengambil resiko dan tampil beda, terbuka terhadap pengalaman baru, menghargai diri sendiri dan orang lain (M. Jazuli, 2008: 104). Dengan demikian anak kreatif selalu memunculkan gagasan baru, orisinil, cemerlang, dan unik. Dalam jagat seni sangat mampu memberikan peluang yang amat luas bagi berkembangnya segala, potensi kreatif anak secara bebas (nyaman) dan menyenangkan karena tidak ada indoktrinasi, tidak mengenal benar dan salah, tetapi 
selalu dalam situasi harmoni. Keadaan semacam ini memungkinkan anak memiliki keberanian untuk mengungkapkan ide dan meningkatkan rasa empati, menyadari kemampuan sendiri, serta siap menerima tanggapan lingkungan terhadap apa yang diungkapkan. Dengan adanya keberanian tersebut pendidik cukup sebagai fasilitator yang berperan memberikan arahan dan pelayanan secara proporsional dan konstruktif. Misalnya: menciptakan suasana yang mampu memotivasi kepada siswa untuk berani mencetuskan idenya, menyediakan sarana yang mendorong eksplorasi dan eksperimen, bersikap komunikatif, serta cerdas dalam menciptakan lingkungan sekolah yang bebas sekaligus tertib. Eisner dan Ecker menginformasikan pendapat tokoh pendidikan seni di Amerika Margaret Mathias, Bella Boas, Florence Cane, dan Victor D'Amico bahwa pendidikan seni potensial untuk mencetak manusia kreatif. Hasil penelitian Mohanty dan Hejmadi tahun 1992 menginformasikan bahwa setelah 20 hari anak belajar menari dan bermusik kemudian diberi tes berpikir kreatif, ternyata hasil skornya lebih tinggi dari anak yang tidak belajar menari dan bermusik. Hal ini menunjukkan bahwa menari dan bermusik dapat meningkatkan daya kreatif. Berdasarkan hasil penelitian tersebut kemudian menyebar ke seluruh penjuru dunia sebagai gerakan pendidikan seni yang mempromosikan kekreatifan (M. Jazuli, 2008: 105).

Ketiga, meningkatkan kepekaan perasaan, khususnya rasa keindahan alam maupun buatan manusia. Orang yang peka perasaannya ditandai oleh kesadaran dan responsif terhadap gejala yang terjadi di sekitarnya. Hal ini tercermin pada kemampuannya untuk menerima, mengamati, dan menghayati berbagai rangsang dari luar. Dengan kata lain, orang yang peka rasa memiliki daya penghayatan tinggi terhadap lingkungannya sehingga relatif mudah menyerap variasi keindahan yang muncul ke permukaan, seperti tergetar bila mendengar suara gemericik air, deburan ombak, alunan seruling, gesekan biola, gerakan tarian, goresan lukisan, ekspresi wajah pengemis dan orang tuli, dan sebagainya. Orang yang peka perasaannya cenderung berpikir dan bertindak positif dan konstruktif terhadap lingkungannya sehingga kemudian mendorong para pendidik untuk mencetak siswa yang peka perasaan melalui pembelajaran apresiasi seni di sekolah umum. Untuk menciptakan kepekaan perasaan siswa dalam proses pembelajaran apresiasi seni ditempuh dengan berbagai cara. Misalnya mengenalkan tokoh seniman besar dan karya-karyanya beserta kisah perjalanan hidupnya melalui foto reproduksi, mendengarkan dan menyimak musik secara cermat, mencermati8 gerakan flora dan fauna serta gerakan tari, mengunjungi galeri, gedung pertunjukan, museum, mengoleksi gambar, foto, kaset, DVD, dan sebagainya. Semua itu dimaksudkan untuk menumbuhkembangkan kepekaan perasaan terhadap keindahan. Kepekaan perasaan sering menjadi modal awal dan utama bagi proses penciptaaan karya seni.

Keempat, menumbuhkan rasa percaya diri dan tanggung jawab. Orang yang memiliki rasa percaya diri berarti dia mampu menyesuaikan diri dan mampu berkomunikasi pada berbagai situasi, memiliki kemampuan bersosialisasi, serta memiliki kecerdasan yang cukup. Implikasi dari rasa percaya diri adalah munculnya sikap mandiri, yang di dalamnya memuat rasa tanggung jawab. Hasil penelitian Atip Nurharini menginformasikan bahwa pembelajaran tari mampu mengembangkan rasa kepercayan diri anak ( M. Jazuli, 2008 : 106). Rasa percaya diri anak dimaksud adalah 
suatu keyakinan atas segala aspek kelebihan yang dimiliki anak, dan dengan keyakinan itu membuat diri anak mampu untuk bisa mencapai berbagai tujuan dan keinginan didalam hidupnya.

\section{Manfaat Belajar Seni Musik Untuk Anak}

Pendidikan musik adalah bidang studi yang terkait dengan pengajaran dan pembelajaran musik. Bidang studi ini mencakup semua aspek pembelajaran, termasuk psikomotor (pengembangan kemampuan), kognitif (pemerolehan pengetahuan) dan afektif, termasuk apresiasi musik dan sensitivitasnya. Keberadaan pelatihan musik mulai dari pendidikan prasekolah sampai pascasekunder umum ditemukan di berbagai negara karena keterlibatan dalam musik dianggap sebagai komponen dasar budaya dan perilaku manusia. Musik, seperti bahasa, adalah pencapaian yang membedakan manusia dengan makhluk lain yang berpengaruh terhadap kecerdasan dan kreativitas seseorang.

Latihan atau pendidikan musik di sebuah Yayasan Kesenian pada usia muda akan sangat membantu perkembangan pada bagian otak tertentu yang digunakan untuk mempelajari bahasa dan daya nalar. Studi yang dilakukan belakangan ini telah menunjukkan bahwa latihan music dapat mengembangkan kemampuan otak kiri yang dalam tugas sehari-harinya memproses informasi atau bahasa yang masuk ke otak dan pada dasarnya membantu otak tersebut mengalirkan sirkuit tertentu pada otak dengan cara tertentu. Memperdengarkan lagu-lagu yang familiar pada saat menangkap informasi baru cenderung meningkatkan daya tangkap pada anak-anak yang masih muda.

Terdapat pula hubungan yang sangat erat antara musik dan daya nalar spasial (spatial intelligence - kemampuan untuk menangkap informasi tertentu dengan cepat dan dapat membuat gambaran secara mental atas hal-hal yang dilihat). Intelegensia seperti ini, dimana seseorang dapat memvisualisasikan berbagai elemen pada saat bersamaan sangat penting fungsinya untuk banyak hal dari menyelesaikan tugas matematika yang kompleks sampai pada kemampuan untuk mengingat apa saja yang akan diperlukan untuk dimasukkan dalam tas sekolah pada hari itu.

Murid-murid yang belajar musik baik secara langsung atau dari Forum Musik cenderung belajar berpikir secara kreatif dan memecahkan masalah dengan cara membayangkan berbagai alternatif solusi yang ada, sehingga menolak ketentuan dan asumsi yang berlaku.

\section{Metode Penelitian}

Metode yang digunakan dalam penelitian ini adalah metode kulaitatif. Sedangkan pendekatan dalam penelitian ini menggunakan pendekatan library research. Dimana penelitian ini berusaha untuk mengetahui bagaimana relevansi pendidikan musik terhadap kecerdasan intelektual pada anak usia dini.

\section{Pengaruh Musik Terhadap Kecerdasan Anak Usia Dini}

Berdasarkan pengamatan pada sejumlah anak, para peneliti dari Universitas California menyimpulkan bahwa belajar musik pada usia dini dapat meningkatkan 
kecerdasan seperti kemampuan bernalar dan berpikir dalam jangka panjang. Hasil penelitian ini begitu menarik perhatian sehingga buku The Mozart Effect karangan Don Campbell (1997), begitu monumental . Menurut Ahli saraf dari Harvard University, Mark Tramo, M.D., getaran musik yang masuk melalui telinga dapat mempengaruhi kejiwaan, Ini terjadi karena didalam otak manusia, terdapat jutaan neuron dari sirkuit secara unik menjadi aktif ketika kita mendengar musik. Neuron-neuron ini menyebar ke berbagai daerah di otak, termasuk pusat auditori di belahan kiri dan belahan kanan. Mulai dari sinilah kaitan antara musik dan kecerdasan terjadi.

Penelitian bagaimana pengaruh musik terhadap kecerdasan juga dilakukan oleh psikolog Fran Rauscher dan Gordon Shaw dari University of California-Irvine, Amerika Serikat pada tahun 1994. Hasil penelitian yang dilakukan membuktikan bahwa erat kaitan antara kemahiran bermusik dengan penguasaan level matematika yang tinggi, dan keterampilan-keterampilan sains. Setelah delapan bulan, penelitian kedua pakar ini menunjukkan bahwa anak-anak yang mendapatkan program pendidikan musik, meningkat inteligensi spasialnya (kecerdasan ruang) sebesar $46 \%$ dibandingkan dengan anak-anak yang tidak diekspos oleh musik.

Bukan hanya sekedar kecerdasan spasial, musik juga meningkatkan kemampuan bahasa dan kosa kata anak serta logika yang pada akhirnya si anak mampu mengorganisasi ide dan mampu memecahkan masalah.

Anak pada usia dini (2-3 tahun) masih sangat berorientasi pada dirinya sendiri, minatnya lebih terarah pada dirinya sendirib dan jarang melakukan aktivitas bersama. Periode ini merupakan periode eksploratif anak-anak. Mereka masih belajar mengendalikan aktivitas anggota tubuhnya, seperti belajar berjalan dan berlari juga masih. Oleh karena itu, sebaliknya rangsangan musik pada periode ini lebih diarahkan pada upaya mendukung kebebasan melakukan aktivitas fisik dan peningkatan kesadaran bagian tubuh (body awareness).

Dalam periode perkembangan ini, anak masih belajar mengkoordinasikan gerak tubuh. Sebaliknya, rangsangan musikal yang diberikan diarahkan untuk mendukung koordinasi gerak tubuh. Musik yang memiliki struktur dan irama yang sederhana, tetapi relative konstan merupakan music yang baik bagi anak-anak dalam periode ini. Struktur sederhana music dapat dibentuk dengan penyusunan lagu dalam batas satu oktaf. Adapun irama musik yang baik bagi anak-anak usia ini umumnya berada pada rentang irama sedang, tidak terlalu cepat, dan tidak pula terlalu lambat. Dalam kajian seni musik, tempo irama ini berada pada tempo Andante - Moderato. Contohnya lagu twinkle twinkle little star. Berikut Tahapan- tahapan aspresiasi perkembangan musik anak usia 2-3 tahun, antara lain :

\section{Menyanyikan Atau Memutar Lagu}

Berdasarkan berbagai studi dan pengamatan, musiK juga membantu orang tua mengubah suasana hati untuk disesuaikan dengan situasi yang baru. Nyanyikan atau putar lagu-lagu yang ditunjukkan untuk menenangkan anak yang berusia 2-3 tahun misalnya ketika tidur ataupun ketika sedang bermain.

\section{Latihan Mengenal Ritme}

Dalam waktu yang tak terlalu lama, si kecil dapat duduk dan mengendalikan gerak tubuhnya. Anak usia 2-3 tahun biasanya sangat suka bereksperimen dengan 
ritme lagu yang didengarnya, turut bertepuk tangan, mengangguk-anggukkan kepala, menderapkan kaki, serta mengetuk-ngetuk sendok pada piring, gelas atau meja untuk mengiringi ritme lagu. Kesempatan ini baik untuk melatih anak menahan diri saat mengikuti ritme. Latihan yang berkaitan dengan pengenalan ritme juga dapat dilakukan dengan mengaktifkan gerakan tubuh, mendecakkan lidah, dan menjetikkan jari sambil membunyikan alat musik.

\section{Belajar Bersenandung}

Anak biasanya belajar bersenandung sejak sebelum dapat menyanyi dengan benar. Dorongan untuk bersenandung secara berulang-ulang biasanya terjadi spontan melalui permainan lompat tali atau lompat katak. Di usia 2-3 tahun, biasanya anak dapat mengikuti sebuah lagu dengan senandung serta nada yang belum pas. Nanana...... nanana...nana," demikian cara si kecil anda yang berusia 2-3 tahun mengekspresikan lagu dalam ingatannya. Ini merupakan langkah awal menstimulasi anak untuk menyanyi dengan sungguh-sungguh

\section{Melakukan Gerak Berirama}

Di usia 2-3 tahun, anak biasanya ekspresi tubuh dan emosinya apabila sedang mendengarkan musik. Di dalam setiap diri anak terdapat musikalitas yang tingkatannya berbeda pada tiap anak.

Sambil anak bersenandung gerak tubuhnya lebih terarah, dan kesukaannya menggoyangkan tubuh mengikuti irama semakin meningkat. Biarkan anak anda yang berusia 2-3 tahun menari di tempat yang dapat memberinya kesempatan untuk melihat gerakan tubuhnya sendiri. Dengan demikian, anak dapat dengan sadr menggerakkan tubuh sesuai yang diinginkan. Demikia pula untuk berhenti. Selain itu yang juga penting, adalah mengendalikan gerak tubuh.

\section{Latihan lagu dan aksi}

"Tanganku ada dua, yang kiri, yang kanan.... " Si kecil dapat menyanyikan lagu ini sambil menunjukkan dua jarinya saat menunjukkan dua jarinya saat mengatakan "ada dua"atau mengangkat kedua tangannya sambil menunjuk yang mana tangan kiri. Latihan dengan mengaktifkan tubuh dan mendomstrasikan dan isi lagu, tentu menyenangkan buat anak, serta sekaligus memberi anak pengetahuan dan kesempatan untuk latihan konsentrasi, selain juga mengenal berbagai konsep sederhana.

\section{Mendengar Musik Bersama}

Dapat dilakukan kegiatan mendengarkan musik bersama anak anda atau setelah si kecil mahir berbicara dalam bentuk kalimat. Simak dengan seksama sebuah potongan lagu yang diputuskan. Putarkan lagu dengan jenis musik yang sesuai dengan kesukaan serta minat anda dan si kecil. Setelah itu, biarkan anak mengenali instrument apa saja yang digunakan dalam lagu tersebut, lalu biarkan ia mengenali ritme yang disuarakan oleh alat masing-masing alat musik. Anda dan si kecil dapat bermain imajinasi dan interprentasi sederhana tentang pengaruh sebuah instrument dalam sebuah lagu.

\section{Menggambar Dengan Musik}

Apabila si kecil yang berusia 2-3 tahun dan suka menggambar, maka kegiataan yang dikombinasikan dengan music tentu akan mengasah kreativitas serta menyimak 
dengan konsentrasi. Mintalah si kecil menorehkan warna atau menggambar apa saja yang ingin digambarkan setelah tergugah perasaan atau inspirasinya oleh lagu atau musik yang diperdengarkan.

8. Membuat Alat Musik

Kita dapat membantu anak yang membuat alat musik sederhana dengan bahan-bahan sederhana contohnya seperti kotak kosong bekas lalu isi dengan sejumlah kerikil. Alat music buatan sendiri ini akan mengeluarkan bunyi khas apabila dihentak-hentak mengikuti irama dan nada lagu yang dinyanyikan.

\section{E. Simpulan}

Berdasarkan hasil penelitian dapat disimpulkan bahwa erat kaitannya antara kemahiran bermain musik dengan kecerdasan intelektual. Anak-anak yang mendapatkan program pendidikan musik, meningkat inteligensi spasialnya (kecerdasan ruang) dibandingkan dengan anak-anak yang tidak diekspos oleh musik. Bukan hanya sekedar kecerdasan spasial, musik juga meningkatkan kemampuan bahasa dan kosa kata anak serta logika yang pada akhirnya si anak mampu mengorganisasi ide dan mampu memecahkan masalah.

\section{DAFTAR PUSTAKA}

Atan Hamdju, dan Armilah Windawati. 1986. Pengetahuan Seni Musik untuk SMA, SPG dan Sederajat Jilid I. Jakarta: Mutiara Sumber Widya

AT. Mahmud. 1996. Musik Di Sekolah Kami. Jakarta: Depdikbud

Depdiknas. 2006. Kurikulum Tingkat Satuan Pendidikan. Jakarta: BSNP

. Kurikulum Tingkat Satuan Pendidikan(KTSP) Mata Pelajaran Seni Budaya dan Keterampilan. Jakarta: Puskur.

. 2007. Model Penilaian Kelas (SD/MI/SDLB). Jakarta: Badan Standar Nasional Pendidikan

2009. Panduan Teknis Festival Kompetensi dan Kreativitas Siswa Sekolah Dasar Tingkat Nasional. Jakarta

Jamalus. 1991. Pendidikan Seni Musik. Jakarta: Depdikbud

Oemar Hamalik. 2006. Pendidikan Guru; Berdasarkan Pendekatan Kompetensi. Jakarta: Bumi Aksara

Rien Safrina. 1999. Pendidikan Seni Musik. Jakarta: Debdikbud

Syafii. 2002. Kertakes. Jakarta: Universitas Terbuka 